\title{
ON ECONOMETRIC MODELS OF THE U.S. ECONOMY
}

\author{
by Carl F. Christ
}

\section{INTRODUCTION 1}

IN this paper I propose to discuss econometric models of the Tinbergen type ${ }^{2}$, as applied to the U.S. economy. Econometric models of the Leontief type also furnish food for thought, but for those mental meals I must refer the reader elsewhere ${ }^{3}$.

Section II summarizes the character of Tinbergen-type models. Section III discusses some of their dynamic properties. Section IV describes some general test procedures that can be applied to econometric models. Section V contains most of the meat of the paper; it presents a comparative survey of nine Tinbergen-type models of the U.S. economy that have appeared in the last seventeen years, including some evidence concerning the ability of four of them to explain or forecast post-sampleperiod data. Section VI is a list of references.

\section{TINBERGEN-TYPE ECONOMETRIC MODELS}

Aggregate econometric models fall quite naturally into two types, which I call the Tinbergen type and the Leontief type, though of course it is possible to combine the two types into one model, or no doubt to devise models that are different from both. The essential character of the Tinbergen-type models may be summarized thus. ${ }^{4}$ There is a system of $\mathrm{N}$ equations. Some of

1 This paper was written during my tenure of a Fulbright Grant for work in Cambridge, England, during 1954-55. I wish to express my appreciation to Professor J. R. N. Stone of the Department of Applied Economics for fruitful discussions of my work and for making available clerical and computing services.

2 See the pioneering and worthwhile study, Tinbergen (1939). References will be given in this form, see the list in Section VI.

${ }^{3}$ Besides the two similarly-titled Leontief volumes (1951 and 1953), good sources are Evans and Hoffenberg (1952), Netherlands Economic Institute (1953), and Conference on Research in Income and Wealth (1955). The latter two are collections of papers on input-output analysis, the last one being devoted to appraisals by several writers. See also the excellent recent report by Stone, Conceptual Problems in Input-Output Work (mimeographed, May 1955). This memorandum was prepared for the O.E.E.C and discussed by a Working Group on Statistics of Capital Formation, Input-Output Tables and Savings convened by the Statistical Commission and Economic Commission for Europe of the United Nations at Geneva in June 1955.

* See Koopmans and Hood (1953), pp. 117-26. 
them are exact definitions derived from considerations of national accounting, such as $\mathrm{C}+\mathrm{I}=\mathrm{Y}$ etc. The others are stochastic equations, of several possible types. Some stochastic equations are meant to describe the behaviour of some important group in the economy, such as consumers or investors in real capital. Some are meant to describe the operation of technological or institutional restraints, and some are meant to describe the kind of adjustment process that takes place in particular markets (for labour or money or goods, etc.) when there is excess demand or supply. All such equations, definitional or stochastic, are called structural equations, for each is supposed to describe the working of some more or less well-defined part of the structure of the economy.

In addition to variables the equations contain unknown parameters, which are supposed to be constant over a certain period or population. There are typically more than $\mathrm{N}$ variables in the system, i.e. more variables than equations. $N$ of these variables are classified as endogenous, and the remainder are classified as predetermined. If the values of the parameters and the predetermined variables are given to the system, then it becomes a system of $\mathrm{N}$ equations with known coefficients and with $\mathrm{N}$ unknowns - the $\mathrm{N}$ endogenous variables - so it can be said to determine the values of the $\mathrm{N}$ endogenous variables, given the values of the parameters and predetermined variables. Strictly speaking, the endogenous variables are not exactly determined by the system because of the stochastic character of the nondefinitional structural equations; only their expected values are so determined.

The essential nature of the predetermined variables, as their name suggests, is that their values are already determined by the time the system sets to work to determine the values of the endogenous variables. The predetermined variables fall into two groups. The first contains those supposed to be determined completely outside the system; they are called exogenous variables. The classic example (which hardly anyone ever uses in a model) is the weather; other possible examples are government policy variables, world market prices or demands, etc. The second group contains variables whose values have been determined by the past working of the system, i.e. lagged endogenous variables. Examples are last period's income, peak previous consumption, etc. 
It is the lagged endogenous variables that give such a system its dynamic character, i.e. its ability to generate changing values of the endogenous variables even when the parameters and exogenous variables and stochastic disturbances are held fixed. For brevity I shall refer to the three last-mentioned groups of factors as the autonomous factors, to distinguish them as a whole from the endogenous variables. Dynamic systems can be devised that will generate cycles and/or long-term growth, even without any changes in the autonomous factors.

The unknown parameters of the structural equations of a model of the Tinbergen type are estimated by fitting them to data giving the values of the endogenous and predetermined variables in several different time-periods. If the equations were exactly correct and the data contained no errors, the fit would be perfect and the values of the parameters could be discovered exactly. ${ }^{l}$ However, the equations are only approximately correct at best, and there are also some errors in the data, so that the fit is almost never exact. There are several fitting techniques available for making estimates in this situation. The two that have been most used in Tinbergen-type models are the least squares and the limited information methods. ${ }^{2}$

\section{DYNAMIC PROPERTIES}

There is an extensive literature on dynamic theories of economic fluctuations and growth, associated with the names of Frisch, Kahn, Keynes, Kalecki, Harrod, Samuelson, Kaldor, Domar, Goodwin, Hicks, and others. This field is closely related to econometric models. One reason is that dynamic economic theories have profoundly influenced the character of the econometric models that have been constructed to try to explain and forecast economic variables. Another reason is that econometric models can provide a medium for discovering how well a particular dynamic theory corresponds to the real world.

Because of this close relation between econometric models and dynamic theories of fluctuations and growth, it may be

\footnotetext{
1 Except for any parameters that are not identified. For a good exposition of this problem see Koopmans (1949)

${ }^{2}$ See, for example, Koopmans and Hood (1953). Another method has been developed by $\mathrm{A}$. Theil which has most of the advantages of the limited information method and is much easier to use. See Theil's forthcoming book.
} 
useful to digress a bit concerning these dynamic theories. There are several devices that can be used to impart a dynamic character to a theory or model.

One device, already mentioned in Section II, is the use of lagged values of some of the endogenous variables, so that events of the current period are influenced by events of the preceding period(s), and events of the next period will be influenced by events of the current period (and possibly preceding periods too), and so on into the future. Typically the symbol $x_{t}$ is used for the value of $x$ in period $t$ or at time $t$, and $\mathrm{x}_{\mathrm{t}-1}, \mathrm{x}_{\mathrm{t}-2}$, etc. accordingly denote the values of $\mathrm{x}$ lagged one period, two periods, etc.

Another device, which is strictly equivalent to the use of lags, is the use of differences between current and lagged variables, denoted by

$$
\triangle \mathrm{x}_{\mathrm{t}}=\mathrm{x}_{\mathrm{t}}-\mathrm{x}_{\mathrm{t}-1}
$$

or differences between these differences,

$$
\begin{aligned}
\triangle^{2} x_{t} & =\triangle\left(\triangle x_{t}\right)=\Delta x_{t}-\triangle x_{t-1} \\
& =x_{t}-2 x_{t \cdot 1}+x_{t \cdot 2}
\end{aligned}
$$

$\triangle x_{t}$ is called the first difference of $x, \triangle^{2} x_{t}$ the second difference of $x$, etc. The equivalence of lags and differences is easy to see from the above definitions. For $\triangle x$ can be expressed in terms of $x_{t-1}$ via the first equation, or vice versa, and $\triangle^{2} x_{t}$ can beexpressed in terms of $x_{t-1}$ and $x_{t-2}$ via the second equation. A similar equation can be derived expressing $\mathrm{x}_{\mathrm{t}-\mathrm{2}}$ in terms of $\triangle \mathrm{x}_{\mathrm{t}}$ and $\triangle^{2} \mathrm{x}_{\mathrm{t}}$, and so forth for higher order lags and differences.

Another device is the use of instantaneous rates of change, i.e. derivatives with respect to time, such as $\mathrm{dx} / \mathrm{dt}$, or rates of change of rates of change, such as the second derivative $\mathrm{d}^{2} \mathrm{x} / \mathrm{dt}^{2}$, etc. Differences and derivatives are two alternative ways of expressing the fact or hypothesis that one variable's value depends inter alia on the rate of change of itself or some other variable. The difference $\Delta x_{t}$ measures the average rate of change of the variable $x$ during the interval between periods $t-1$ and $t$. The derivative $\mathrm{dx} / \mathrm{dt}$ measures the instantaneous rate of change of $x$ at any particular moment $t$. Using differences (or lags) gives rise to mathematical difference equations; using derivatives gives rise to differential equations. ${ }^{\mathrm{I}}$ Either type of equation can

${ }^{x}$ If one uses both differences (or lags) and derivatives, the result is mixed difference-differential equations. 
generate fluctuations and growth, the former in terms of small jumps made once per period, the latter in terms of smooth, continuous changes. Which to use is a matter of choice. Econometric models to date have used differences almost exclusively, and I shall do the same. ${ }^{x}$

Another device is the use of cumulated variables, such as capital stock as the cumulation of net investment in the past, etc. Such cumulated variables can easily be combined in the same model with either differences or derivatives.

Suppose that the $\mathrm{N}$ structural equations of a model are solved for the $\mathrm{N}$ endogenous variables in terms of the autonomous factors and predetermined variables. ${ }^{2}$ The result is called the reduced form, and each of its equations may be used to forecast one endogenous variable when the values of its parameters ${ }^{3}$ and the predetermined variables are known. But the reduced form is not suitable for analysing the time-path of endogenous variables generated by the model, for it typically expresses each endogenous variable as a function of exogenous variables and the lagged values of several endogenous variables. To analyse the time-path of an endogenous variable, one wants an equation expressing that variable in terms of lagged values of itself (but not of other endogenous variables) and exogenous variables. Such equations are called final equations, ${ }^{4}$ and in principle they may always be obtained from the reduced form by algebra. ${ }^{5} \mathrm{~A}$ final equation is a difference equation in one endogenous variable, with coefficients depending on the parameters and exogenous variables of the model. Such a difference equation itself has a solution, with the following property: if enough consecutive values of the endogenous variable in question are known, say $\mathrm{x}_{0}, \mathrm{x}_{1}, \mathrm{x}_{2} ;{ }^{\mathrm{G}}$ and if from that point onwards the parameters of the model and the exogenous variables are held fixed at known values, then the endogenous variable $x$ will trace out a determinate time-path of values $x_{3}, x_{4}, x_{5}$, etc. forever,

${ }^{1}$ The advantages of difference equations are that observations of economic flows are usually available for calendar periods, and that they are more familiar to most economists. The main advantage of differential equations, and an important one, is that an extensive body of mathematical results concerning them is available and ready to be applied.

2 Defined above in Section II.

${ }^{3}$ The reduced form parameters are functions of the parameters of the structural equations.

${ }^{4}$ The term is due to Tinbergen (1939), p. 130.

G But see p. 10, note 4.

6 'Enough' means as many as there are lags in the equation. 
and the solution of the final difference equation gives the value of $x$ at every future time as a function of $t$. The lags in the reduced form are the same as those in the structural equations, but there are typically more and longer lags in the final equation than in the structure or reduced form because the number of variables in a difference equation cannot be decreased in general without increasing the number and length of lags. ${ }^{1}$

To summarise the descriptions of the structural equations, reduced form, final equations, and the latter's solutions: (1) The structural equations describe the interrelations of all the endogenous variables, conditioned by parameters and predetermined variables; each structural equation may contain several endogenous variables and describes a more or less well-defined part of the structure of economy. (2) Each reduced form equation gives one endogenous variable as a function of predetermined variables, including lagged values of the other endogenous variables if they appear in the model. (3) Each final equation gives one endogenous variable as a function of its own lagged values and of exogenous variables, so that if the exogenous variables and enough initial values of that endogenous variable are given, the final equation can determine the next value of the endogenous variable, then the next, and so on. (4) The solution of a final equation gives the future values of the relevant endogenous variable directly, as a function of time.

An example is provided by a familiar simple linear multiplieraccelerator model, ${ }^{2}$ where $\mathrm{c}=$ induced consumption, $\mathrm{i}=$ induced investment, $\mathrm{g}=$ autonomous expenditure (by consumers, investors, and government), and $y=$ income. Let the structural equations (denoted by the letter $S$ at the right) be

$$
\begin{aligned}
& \mathrm{y}_{\mathrm{t}}=\mathrm{c}_{\mathrm{t}}+\mathrm{i}_{\mathrm{t}}+\mathrm{g}_{\mathrm{t}} \\
& \mathrm{c}_{\mathrm{t}}=\alpha \mathrm{y}_{\mathrm{t}-1} \\
& \mathrm{i}_{\mathrm{t}}=\beta \triangle \mathrm{y}_{\mathrm{t}-\mathrm{1}}=\beta\left(\mathrm{y}_{\mathrm{t}-1}-\mathrm{y}_{\mathrm{t}-2}\right)
\end{aligned}
$$

Here current consumption depends on lagged income and current investment depends on the lagged change in income. The reduced form is obtained by solving for $y_{t}, c_{t}$, and $i_{t}$ in terms of the predetermined variables $y_{t-1}, y_{t-2}$, and $g_{t}$. In this simple case

1 The general rule is that except in rare cases a system of $\mathrm{N}$ equations with lags up to $L$ periods can be transformed by algebra to an equivalent system consisting of just one equation with lags up to at most LN periods. See Samuelson (1947), pp. 384-87.

See for example Samuelson (1939), Hicks (1950). 
equations (2) and (3) are already in the reduced form, for each contains only one unlagged endogenous variable. Hence the reduced form (denoted by the letters RF at the right) consists of (2), (3), and the following equation for $y_{t}$ obtained by substituting (2) and (3) in (1):

$$
\mathrm{y}_{t}=(\alpha+\beta) \mathrm{y}_{\mathrm{t}-1}-\beta \mathrm{y}_{\mathrm{t}-\mathrm{2}}+\mathrm{g}_{\mathrm{t}}
$$

In this simple case equation (4) is already a final equation as well as a reduced form equation, for it contains no lagged values of endogenous variables other than $y$ itself. Hence the final equations (denoted by the letters $\mathrm{FE}$ at the right) consist of (4) and the following two equations for $c_{t}$ and $i_{t}$, obtained by repeated substitution from the reduced form:

$$
\begin{aligned}
& \mathrm{c}_{\mathrm{t}}=(\alpha+\beta) \mathrm{c}_{\mathrm{t}-1}-\beta \mathrm{c}_{\mathrm{t}-2}+\alpha \mathrm{g}_{\mathrm{t}-1} \\
& \mathrm{i}_{\mathrm{t}}=(\alpha+\beta) \mathrm{i}_{\mathrm{t}-1}-\beta \mathrm{i}_{\mathrm{t}-2}+\beta\left(\mathrm{g}_{\mathrm{t}-1}-\mathrm{g}_{\mathrm{t}-2}\right)
\end{aligned}
$$

The final equations are all second-order difference equations. They have exactly the same form except for the effect of the exogenous variable $g$; this is always true of a model whose equations are linear, no matter how many lags or exogenous variables it has. The solution of the final equation (4) for $y_{t}$, assuming the parameters and exogenous variable to be held fixed at the values $\alpha, \beta$, and $\mathrm{g}_{0}$ respectively, is the following function of time, where $\mathrm{K}_{1}$ and $\mathrm{K}_{2}$ are two arbitrary constants that depend on the arbitrary initial values taken by $\mathrm{y}$ at the initial periods $\mathrm{t}=0$ and $\mathrm{t}=1$ :

$$
\text { (7) } \begin{array}{r}
\mathrm{y}_{\mathrm{t}}=\frac{\mathrm{g}_{\mathrm{o}}}{1-a}+\mathrm{K}_{1}\left(\frac{a+\beta+\sqrt{(\alpha+\beta)^{2}-4 \beta}}{2}\right)^{\mathrm{t}} \\
+\mathrm{K}_{2}\left(\frac{a+\beta-\sqrt{(\alpha+\beta)^{2}-4 \beta}}{2}\right)
\end{array}
$$

This may be simplified by renaming the expressions in parentheses $\lambda$, and $\lambda_{2}$ respectively, thus:

$$
\mathrm{y}_{\mathrm{t}}=\frac{\mathrm{g}_{0}}{1-a}+\mathrm{K}_{1} \lambda_{1}{ }^{\mathrm{t}}+\mathrm{K}_{2} \lambda_{2}{ }^{\mathrm{t}}
$$

Note that the expression $g_{0} /(1-a)$ is the static equilibrium income level for the system (1)-(3), i.e. the value of y which, if attained for two successive periods, will be maintained in- 
definitely. ${ }^{2}$ The remainder of the solution, i.e. the sum of the two exponential functions of $t$, is the deviation of $y_{t}$ from its static equilibrium value. The solutions of (5) and (6) for $c_{t}$ and $i_{t}$ are similar, but with different arbitrary constants and different equilibrium values.

In general a linear difference-equation model gives rise to final equations of the form.

$$
\mathrm{x}_{\mathrm{t}}+\mathrm{a}_{1} \mathrm{x}_{\mathrm{t}-\mathrm{1}}+\ldots+\mathrm{a}_{\mathrm{K}} \mathrm{x}_{\mathrm{t}-\mathrm{k}=\mathrm{b}}
$$

where the a's and $b$ depend on autonomous factors. If these autonomous factors are held constant and $K$ initial values of $x$ are given, the the solution of (9) is typically of the following form where $\bar{x}$ is the static equilibrium value of $\mathrm{x}$ corresponding to the given autonomous factors; $A_{1} \ldots, A_{K}$ are arbitrary constants depending on the initial values of $\mathrm{x}$; and $\lambda_{1}, \ldots, \lambda_{\mathrm{K}} \mathrm{a}$ the roots of the characteristic equation of (9). ${ }^{2}$

$$
\mathrm{x}_{\mathrm{t}}=+\mathrm{xA}_{1} \lambda_{1}^{\mathrm{t}}+\ldots+\mathrm{A}_{\mathrm{K}} \lambda_{\mathrm{K}}{ }^{\mathrm{t}}
$$

The first few values of $x_{t}$ after the initially given ones are greatly influenced by the A's, and hence by those initial values of $\mathrm{x}$. After several periods have passed, the exponents in (10) increase in size so that the $\lambda$ 's with the smaller absolute values begin to fade away in relative importance, and eventually the largest characteristic root (in absolute value) dominates the others completely and determines the behaviour of $x$.

If this largest root is greater than 1 in absolute value, $x$

${ }^{1}$ This can be seen either by dropping all subscripts in (1)-(3) and solving the resulting static system for $y$, obtaining $y=g /(1-a)$; or by substituting $g_{o} /(1-a)$ for $y_{t-1}$ and $y_{t-2}$ in (4) and obtaining $y_{t}=g_{o} /(1-a)$.

2 The characteristic equation of (9) is $\lambda^{k}+a_{1} \lambda^{k-1}+\ldots+a_{k-1} \lambda+a_{k}=0$ and $\lambda_{1}, \ldots, \lambda_{K}$ are its roots. Equation (7) was derived in this way, as the reader may verify if he wishes. Equation (10) must be modified somewhat if two or more of these roots are identical, but in practice this is highly unlikely. See Baumol (1951), pp. 177-81. The discussion in the text above concerns the behaviour of a linear system with fixed and constant values of parameters and exogenous variables. Such a system has a static equilibrium position which if attained for a minimum number of periods will be maintained, in the absence of disturbances. The discussion still applies, with suitable small modifications, to a linear system in which some of the parameters and exogenous variables are fixed and constant but some are constrained to vary in a regular and preassigned manner, such as by increasing arithmetically or geometrically at a given rate. Such a system has a dynamic equilibrium path which if followed for a minimum number of periods will be followed indefinitely, in the absence of disturbances. The formal analysis of the two systems is similar; indeed equation (10) above provides the solution of the dynamic case if $\bar{x}$ is interpreted as the moving equilibrium value of $x$ in period $t$ instead of as the static equilibrium value. For an illuminating account of these matters, see Hicks (1950), pp. 83-86 and the material leading up to there. 
eventually 'explodes', i.e. increases exponentially, and the system is unstable. Such a model need not be unrealistic, however, even over long intervals of time: if the largest root were equal to about 1.02 or 1.03 , with annual periods, this would correspond to a steady growth of income at the rate of about 2 to 3 per cent a year. Thus an unstable system is not out of the question provided its rate of 'explosion' or growth is reasonable. If the largest root is less than 1 in absolute value, $x$ eventually returns exponentially toward its equilibrium, and the system is stable.

If the largest root is real and positive, the eventual motion of $\mathrm{x}$ is monotonic. If the largest root is real and negative, the eventual motion of $\mathrm{x}$ is oscillatory, positive in even-numbered periods and negative in odd. And if the largest root is complex, of the form $p+i q$ where $i=\sqrt{-1}$, then it will have a 'twin' of the form $\mathrm{p}-\mathrm{iq}$, and the eventual motion of $\mathrm{x}$ will be cyclical. The monotonic or oscillatory or cyclical movement will be explosive or damped as indicated in the foregoing paragraph.

A great deal of interest has attached to these conditions concerning the largest characteristic root, for the presence or absence of stability and cycles are important questions. But as we have seen, these conditions apply only to the later part of the time-path, after a few periods have passed so that the influence of the initial conditions and the smaller characteristic roots has begun to die away. In practice we never get to the later part of such a time-path, for some of the exogenous variables change after a year or two and we then find ourselves at the beginning of a new time-path with new initial values. ${ }^{1}$ Hence these conditions about the largest root are not practically very useful. It is more useful to analyse the early part of the time-path the first two or three periods after the beginning. To take a homely example, it is probably more useful to know the effects over each of the first three years after government expenditure has been set at a new level than to know the conventional multiplier, which gives the effect after an infinite or at any rate a large number of years, because further changes in government expenditure or other exogenous variables can be expected to set the economy on a new time-path after a year or two.

Even if we did experience long periods with unchanged

I Recall that the parameters of the final difference equations (9) or (4)-(6) depend upon the structural parameters and upon the values of the exogenous variables; thus changing any of the exogenous variables changes the final equations, and this is why it changes the time-path. 
exogenous variables so that the largest characteristic root had a chance to assert itself over the others, it would still be important to analyse the early part of the time-path, the part before the largest root comes to dominate the others, because it is at least as interesting to know how a system would behave in the immediate future as in the more distant future. For example, if a certain policy, applied now and continued, would eventually lead to a steady growth at 3 per cent a year, it still may not be a very attractive policy if its effects over the first five years are undesirable even though temporary.

So far in this paper the formal discussion of final equations and the behaviour of their solutions has been in terms of linear systems of structural equations. Nonlinear systems are at least as important, however, and indeed all of the larger models of the Tinbergen type contain nonlinearities. The theory of nonlinear difference equations is much less fully worked out than that of linear ones, ${ }^{1}$ and hence for nonlinear models the final equations and their solutions are much more difficult to work out. It is interesting to note that while a linear difference equation must have at least two lags in order to generate cycles, ${ }^{2}$ a suitable nonlinear equation with one lag can generate cycles. ${ }^{3}$

The chief advantage of nonlinear equations for econometrics is that they offer a wider range of choice to the economist trying to construct a realistic model. The chief disadvantage of course is that they are harder to analyse mathematically, to such an extent that for nonlinear models the reduced forms and final equations and their solutions are almost never explicitly worked out. ${ }^{4}$ This is not in fact as bad as it may seem, for the later part of a time-path is not of much practical interest, as I have argued above, while fortunately the earlier and more interesting part can usually be calculated from the structural equations by

${ }^{1}$ And also less fully than that of non-linear differential equations, which is an argument in favour of using the latter where one wishes to introduce nonlinearity.

${ }^{2}$ This is because it must have some complex characteristic roots, which can occur only in pairs; see note 1 on p. 8 .

${ }^{3}$ For two good papers on recent dynamic theories of fluctuations and growth, which illustrate this point, see Matthews (1954) and Ichimura (1954). They are two consecutive papers in the same volume, the first non-mathematical and the second mathematical (using differential equations, quite simple in the first few cases presented).

4 Indeed, a polynomial equation of higher than 4th degree cannot be solved by algebraic methods at all; numerical solutions can be obtained when the coefficients are numerically given, however. 
numerical approximation methods without obtaining the final equations or the reduced form explicitly. 1

\section{TESTING ECONOMETRIC MODELS ${ }^{2}$}

The work is only half done when an econometric model has been constructed and its parameters have been estimated. Such a model is meant to correspond to certain elements of the real world and the next task is to see how well it does so. The parameters are estimated by a process of fitting to a certain set of data, the sample data. The question then arises whether the model (with its numerical parameters) corresponds to other data also. This question arises for at least two reasons. First, as seekers after truth and understanding, economists wish to establish models which describe as large a part of economic experience as possible. Second, as decision-makers or advisers of decision-makers, economists wish to be able to forecast economic events in at least the near-term future, and to forecast the consequences of alternative decisions.

There is a difficulty in judging a model on the basis of how well it describes new data, because one is never quite sure that the structure ${ }^{3}$ underlying the new data is the same as the structure underlying the sample data. For example, if one finds that a model based on U.S. interwar data does not describe U.S. postwar data very well, one is faced with the choice between these two conclusions: $(a)$ The structure in the postwar period is the same as in the interwar period but the model is wrong, having been lucky enough to get by in the interwar period but having been shown up in the postwar period. Or $(b)$ The structure in the postwar period is different from that in the interwar period, and the model is correct for the interwar period, but it cannot be expected to describe the data under the new changed structure. It is impossible to tell rigorously which conclusion is correct. One can only try, on the one hand, to devise a model which describes both sets of data well, or, on the other hand, to devise a separate model for each and then find other evidence that would lead one to expect a change of

\footnotetext{
1 See for example KIein and Goldberger (1955), pp. 37-40, 72, 75, 78-85, 112-14.

The discussion in this section is conducted in terms of Tinbergen-type models but the basic point of view applies to all econometric models.

${ }^{3}$ See Marschak (1947 and 1953); Koopmans (1949).
} 
structure of a type that would explain the difference between the interwar and postwar models. Conceivably both of these efforts might succeed; then one would have two particular models, one interwar and one postwar, each a special case of a single more general model. This of course would be the ideal outcome. If it occurred say in 1955, then after another few years the whole question would arise again, this time concerning pre1955 and post-1955 data.

Tests can be based on the errors made by structural equations, or the errors made by reduced form equations. In the former case, one finds which structural equations describe reality well and which do not, but one does not learn much about the ability of the whole model to forecast the endogenous variables when predetermined variables are estimated or known. In the case of the reduced form equations errors, the situation is just the reverse. Thus for assessing the forecasting ability of the model as a whole, the errors of the reduced form equations are most relevant, and for judging individual structural equations, the errors of structural equations are most relevant.

There are at least two general sorts of question one can ask about an equation's errors in describing extra-sample data. One is: are these extra-sample errors so large in comparison with the errors (i.e. residuals) within the sample that the equation does not describe the extra-sample data as well as the sample data? If so, either the equation must be rejected or one must conclude that the structures underlying the two sets of data are different. Even if an equation is not rejected by this test, however, the only thing one can thereby claim for it is that it describes the extrasample data as well as the sample data; and it may describe the sample data well or badly in terms of the answer to the second type of question to which we now turn. The second type of question is: are these extra-sample errors so large as to render the model useless as a practical forecasting device? If so, then obviously the model is not a practical forecaster. Both questions are important in testing a model.

\section{A COMPARATIVE SURVEY OF NINE TINBERGEN-TYPE MODELS}

The nine Tinbergen-type models of the U.S. economy which I wish to survey briefly in this section are those of

Tinbergen (1939) 
Clark (1949)

Klein (1950), Models I and III

Christ (1951)

Barger and Klein (1954)

Klein and Goldberger (1955), Models 1 and 2

Valavanis-Vail (1955).

Of these nine models, three are linear and six are not. All are dynamic, using difference equations. Six use years as their periods, two use quarters, and one uses decades. Five are confined to the interwar period, three include some postwar years besides, and one covers the span from 1869 to 1948. Three have as few as six equations (including definitions), one has forty-eight, and the rest have from fourteen to twenty. And so on. To make this welter of detail easier to apprehend, I have set out what I consider to be the major features of these nine models, apart from their performance in extrapolation to postsample data, in Table $\mathrm{I}$. The extrapolation performances of the four large models that to my knowledge have been extrapolated are summarized in Table II. ${ }^{1}$ These two tables are the heart of this section, and they should be read, for their contents are not repeated in the text. Indeed, it was to make comparison easy that I chose to put the material in tabular form instead of in a running text.

The next few paragraphs comment briefly on certain of the features described in Table $I$.

Lagged consumption has found a good deal of favour as a variable in the consumption function, appearing in the five most recent models along with one or more income or output variables. These consumption functions seem in reasonably close accord with those used in theoretical Keynesian models. ${ }^{2}$

There is less accord concerning investment functions. Some are gross and some are net. Some models divide investment into several components and some do not. Some of the econometric models and most of the theoretical models include sales or output as a variable, and some econometric models use property

\footnotetext{
${ }^{1}$ These are Klein's Model III, my model, Valavanis-Vail's model, and Klein and Goldberger's Model I.

${ }^{2}$ For a different but valuable approach to the consumption function, see Modigliani and Brumberg (1954) and Brumberg (1955). The latter estimates a consumption function from data including the war years. For another approach, similar to Modigliani's and Brumberg's, see Milton Friedman's forthcoming book.
} 
income or profit or the profit rate on capital instead. Most include the capital stock. As Table II p. 17 indicates, investment equations are among the least satisfactory in terms of accuracy.

Government expenditures and tax receipts are among the exogenous variables in nearly every model. It is surprising to find government expenditure lumped with investment, and taxes apparently ignored, in Valavanis-Vail's model. The quantity of money, which he includes, can be expected to help fill the gap caused by the absence of government expenditures and taxes, however.

Most of the recent models contain an equation representing the business sector's demand for labour, and explaining the total real wage-bill. This equation or something like it is necessary in a model that makes separate mention of labour income and property income, as when investment is regarded as a function of property income. Most also contain a wageadjustment equation, meant to describe the response of the labour market to the degree of unemployment and possible to changes in the price level. The use of this equation together with the wage-bill equation introduces nonlinearities into the system, for they require the presence of a nonlinear identity to the effect that the real wage bill is equal to the real wage rate times the input of labour. With that, the quantity of labour input is introduced, and this makes it natural to include a production function, which is done in all the larger models after Klein's Model III. The price level enters as an explicit variable unless the wage adjustment equation is stated in terms of real wages, which is less realistic than in terms of money wages.

Tinbergen's model has a large number of equations for the financial sector. The recent large models contain one or more money-market equations, but in most of these cases it happens that they can be dropped without affecting the completeness of the system because they explain variables that do not appear anywhere else in the system in unlagged form. ${ }^{l}$

Tinbergen's model is the only one of the nine that includes money values, real values, and price levels for several of the important flows such as consumption, investment, output, etc.

With the exception of Clark's model which includes peak previous GNP as a determinant of consumption, the dynamic

${ }^{I}$ For the purpose of finding the final equations, it is not legitimate to drop such equations, for to do so reduces incorrectly the order of the final equation obtained. 
TABLE I Comparison of Nine Tinberg-Type Models

\begin{tabular}{|c|c|c|c|c|c|c|c|c|c|c|}
\hline Model & $\begin{array}{c}1 \\
\text { Sample } \\
\text { Period } \\
\text { and } \\
\text { Time } \\
\text { Units }\end{array}$ & $\begin{array}{c}2 \\
\text { Linear } \\
\text { in } \\
\text { Vari- } \\
\text { ables }\end{array}$ & 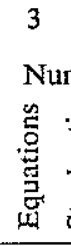 & 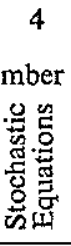 & 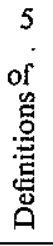 & $\begin{array}{c}6 \\
\text { Variables in the } \\
\text { Consumption } \\
\text { Equation } \\
\text { (Consumption is in } \\
\text { real terms with } \\
\text { one exception) }\end{array}$ & $\begin{array}{l}\text { Variables in the Main } \\
\text { lnvestment Equation } \\
\text { (Investment is in } \\
\text { real terms) }\end{array}$ & $\begin{array}{c}8 \\
\text { Number of Investment } \\
\text { Equations; Other } \\
\text { Components Besides } \\
\text { the Main One }\end{array}$ & $\underset{\text { Variables }^{\mathrm{aa}}}{\text { Main Exogenous }}$ & $\begin{array}{l}\text { Other Important } \\
\text { Economic Features }\end{array}$ \\
\hline $\begin{array}{l}\text { Tinbergen } \\
(1939)\end{array}$ & $\begin{array}{c}1919-32 \\
\text { years }\end{array}$ & No'b & 48 & 42 & 6 & $\begin{array}{l}\text { Wages }+ \text {-salaries } \\
\text { Nonlabour income } \\
\text { Capital gains } \\
\text { Price levels } \\
\text { Time }\end{array}$ & $\begin{array}{l}\text { Corporate profit } \\
\text { Share yields } \\
\text { Price levels } \\
\text { Also lagged values of all } \\
\text { the above }\end{array}$ & $\begin{array}{l}\stackrel{3}{3} \\
\text { Housing construction } \\
\text { Inventory }\end{array}$ & $\begin{array}{l}\text { Agricultural supply } \\
\text { Exports and imports } \\
\text { Building costs } \\
\text { Required bank reserves } \\
\text { Various financial items }{ }^{{ }^{\circ} \mathrm{b}}\end{array}$ & $\begin{array}{l}\text { Explains real and money } \\
\text { yariables and prices } \\
\text { Has a detailed financial sector }\end{array}$ \\
\hline Clark (1949) & $\begin{array}{l}1921-41 \\
\text { quarters }\end{array}$ & Yes & 6 & 4 & 2 & $\begin{array}{l}\text { GNP } \\
\text { Peak previous GNP }\end{array}$ & $\begin{array}{l}\text { GNP } \\
\text { Cumulated investment } \\
\text { over the past } 10 \text { years } \\
\text { (G) }\end{array}$ & $\begin{array}{l}\text { Construction } \\
\text { Inventory }\end{array}$ & $\begin{array}{l}\text { Government expenditure } \\
\text { Deflated bank deposits }\end{array}$ & \\
\hline $\begin{array}{l}\text { Klein (1950) } \\
\text { Model I }\end{array}$ & $\begin{array}{l}1922-41 \\
\text { years }\end{array}$ & Yes & 6 & 3 & 3 & $\begin{array}{l}\text { Wages +salaries } \\
\text { Nonlabour income }\end{array}$ & $\begin{array}{l}\text { Nonlabour income } \\
\text { (current and lagged) } \\
\text { Capital stock } \\
(\mathrm{N})\end{array}$ & 1 & $\begin{array}{l}\text { Government expenditure } \\
\text { Taxes }-1 \text { corporate saving }\end{array}$ & Wage-bill equation \\
\hline $\begin{array}{l}\text { Klein (1950) } \\
\text { Model III }\end{array}$ & $\begin{array}{c}1922-41^{1 a} \\
\text { years }\end{array}$ & No & 15 & 12 & 3 & $\begin{array}{l}\text { Disposable income } \\
\text { Time }\end{array}$ & $\begin{array}{l}\text { Business sales (current } \\
\text { and lagged) } \\
\text { Capital stock } \\
\text { (N) }\end{array}$ & $\begin{array}{l}\text { Construction of housing for } \\
\text { (a) owner-occupiers } \\
\text { (b) Tenancy } \\
\text { Inventory }\end{array}$ & $\begin{array}{l}\text { Government expenditure } \\
\text { Taxes + corporate saving } \\
\text { Excise taxes } \\
\text { Capital goods prices } \\
\text { Excess reserves }\end{array}$ & $\begin{array}{l}\text { Wage-bill equation } \\
\text { Housing market equations } \\
\text { Output adjustment equation } \\
\text { Explains general prices, rent, } \\
\text { and interest rate }\end{array}$ \\
\hline Christ (1951) & $\begin{array}{l}1922-41^{1 a} \\
1946-47 \\
\text { years }\end{array}$ & No & 14 & 10 & 4 & $\begin{array}{l}\text { Disposable income } \\
\text { Deffated quantity of } \\
\text { money } \\
\text { (Lagged consump- } \\
\text { tion later found } \\
\text { helpful) }\end{array}$ & $\begin{array}{l}\text { Business sales (current } \\
\text { and lagged) } \\
\text { Capital stock } \\
\text { (N) }\end{array}$ & $\begin{array}{l}4 \\
\text { Construction of housing for } \\
\text { (a) owner-occupiers } \\
\text { (b) Tenancy } \\
\text { Inventory }\end{array}$ & $\begin{array}{l}\text { Government expenditure } \\
\text { Taxes + corporate saving } \\
\text { Excise taxes } \\
\text { Capital goods prices } \\
\text { Quantity of Money }\end{array}$ & $\begin{array}{l}\text { Wage-bill equation } \\
\text { Housing market equations } \\
\text { Production function } \\
\text { Explains general prices, rent, } \\
\text { wage rate, and interest rate }\end{array}$ \\
\hline $\begin{array}{l}\text { Barger and } \\
\text { Klein (1954) }\end{array}$ & $\begin{array}{l}1923-40 \\
\text { quarters }\end{array}$ & Yes & 6 & 3 & 3 & $\begin{array}{l}\text { Disposable income } \\
\text { Lagged consumption }\end{array}$ & $\begin{array}{l}\text { Nonlabour income } \\
\text { (current and lagged) } \\
\text { Capital stock } \\
\text { (N) }\end{array}$ & 1 & $\begin{array}{l}\text { Government expenditure } \\
\text { Taxes + corporate saving }\end{array}$ & Wage-bill equation \\
\hline $\begin{array}{l}\text { Klein and } \\
\text { Goldberger } \\
\text { (1954) } \\
\text { Model } 1\end{array}$ & $\begin{array}{l}1929-41 \\
1946-50 \\
\text { years }\end{array}$ & No & 19 & 14 & 5 & \multirow{2}{*}{$\begin{array}{l}\text { Separate disposable } \\
\text { incomes of } \\
\text { (a) labour } \\
\text { (b) farm proprietors } \\
\text { (c) all others } \\
\text { Lagged consumption } \\
\text { Consumers' cash } \\
\text { balances } \\
\text { Population }\end{array}$} & \multirow[t]{2}{*}{$\begin{array}{l}\text { Lagged disposable } \\
\text { nonlabour income } \\
\text { Capital stock } \\
\text { Business cash balances } \\
\quad(G)\end{array}$} & 1 & \multirow{2}{*}{$\begin{array}{l}\text { Government expenditure } \\
\text { Direct taxes (allocated to } \\
4 \text { income-components; see } \\
\text { consumption function) } \\
\text { Indirect taxes } \\
\text { Population and labour } \\
\text { force components } \\
\text { Excess reserves } \\
\text { Weekly working hours. } \\
\text { Import prices }\end{array}$} & \multirow{2}{*}{$\begin{array}{l}\text { Wage-bill equation } \\
\text { Production function } \\
\text { Wage adjustment equation } \\
\text { Depreciation equation } \\
\text { Corporate saving equation } \\
\text { Import equation } \\
\text { Farm income equation } \\
\text { Explains general prices, wagc } \\
\text { rate, and interest rates }\end{array}$} \\
\hline $\begin{array}{l}\text { Klein and } \\
\text { Goldberger } \\
\text { (1955) } \\
\text { Model } 2\end{array}$ & $\begin{array}{l}1929-41 \\
1946-52\end{array}$ & No & 20 & 15 & 5 & & & & & \\
\hline $\begin{array}{l}\text { Valavanis- } \\
\text { Vail (1955) }\end{array}$ & $\begin{array}{l}1869-78 \\
\text { to } \\
\text { 1939-48 } \\
\text { over- } \\
\text { lapping } \\
\text { decades }\end{array}$ & No & 18 & 11 & 7 & $\begin{array}{l}\text { NNP } \\
\text { Lagged consumption } \\
\text { (Equation on a per } \\
\text { capita basis) }\end{array}$ & $\begin{array}{l}\text { Gross return to capital } \\
\text { Long-term interest rate } \\
\text { (Equation explains the } \\
\text { ratio of investment to } \\
\text { capital stock) }\end{array}$ & $\begin{array}{l}1 \\
\text { (includes government } \\
\text { expenditure) }\end{array}$ & $\begin{array}{l}\text { Quantity of money } \\
\text { Weekly working hours } \\
\text { Labour force } \\
\text { Death rate } \\
\text { Immigration }\end{array}$ & $\begin{array}{l}\text { Production function } \\
\text { Wage adjustment equation } \\
\text { Depreciation equation } \\
\text { Resource allocation equations } \\
\text { Liquidity preference equation } \\
\text { Explains general prices, wage } \\
\text { rate, and interest rate }\end{array}$ \\
\hline
\end{tabular}




\begin{tabular}{|c|c|c|c|c|}
\hline $\begin{array}{l}\text { c Devices in } \\
\text { ie Model }\end{array}$ & Reduced Form Equations & Final Equations & \begin{tabular}{|c|}
14 \\
Estimation \\
Methods \\
Ma
\end{tabular} & $\begin{array}{c}15 \\
\text { Extra- } \\
\text { polations } \\
\text { to Post- } \\
\text { Sample } \\
\text { Data }\end{array}$ \\
\hline $\begin{array}{l}4 \text { years } \\
\text { investment and } \\
\text { profits }\end{array}$ & $\begin{array}{l}\text { Linear, after some simplification } \\
\text { of the model }{ }^{15 i}\end{array}$ & $\begin{array}{l}\text { Final equation for corporate } \\
\text { profit (after some simplification } \\
\text { of the model }{ }^{13 a} \text { ) is a } 4 \text { th order } \\
\text { linear difference equation, } \\
\text { generating damped cycles } \\
\text { about } 5 \text { years long (p. 140) }\end{array}$ & LS & No \\
\hline $\begin{array}{l}6 \text { quarters } \\
\text { investment over } \\
40 \text { years } \\
\text { us GNP }\end{array}$ & Linear & $\begin{array}{l}\text { Final equations contain lags up } \\
\text { to } 40 \text { years because of } \\
\text { cumulated variables in the } \\
\text { housing equation }\end{array}$ & LS & No \\
\hline $\begin{array}{l}\text { ear } \\
\text { investment }\end{array}$ & Linear & $\begin{array}{l}\text { Final equation for NNP is a } 3 \text { rd } \\
\text { order linear difference } \\
\text { equation, generating mildly } \\
\text { damped cycles (pp. } 76-7 \text { ) }\end{array}$ & $\begin{array}{l}\text { LS } \\
\text { LI } \\
\text { FID }\end{array}$ & No \\
\hline $\begin{array}{l}\text { nd } 2 \text { years } \\
\text { investment }\end{array}$ & $\begin{array}{l}\text { Reduced form equation for } \\
\text { disposable income is of } 3 r \text { rd } \\
\text { degree; similarly for price } \\
\text { level; not worked out (see } \\
\text { Christ (1950), p. 125) }\end{array}$ & Not worked out & LS & $\begin{array}{c}\text { Yes } \\
\text { In Christ } \\
(1951)\end{array}$ \\
\hline $\begin{array}{l}\text { nd } 2 \text { years } \\
\text { investment }\end{array}$ & $\begin{array}{l}\text { Reduced form equation for } \\
\text { disposable income is of } 5 \text { th } \\
\text { degree; same for price level } \\
\text { (p. 125); not given }\end{array}$ & Not worked out & $\begin{array}{l}\text { LS } \\
\text { LI }\end{array}$ & Yes \\
\hline $\begin{array}{l}12 \text { quarters } \\
\text { investment }\end{array}$ & Linear & Not worked out & $\stackrel{\mathrm{R}}{\mathrm{R}}$ and $\mathrm{LI}$ & Yes \\
\hline $\begin{array}{l}\text { nd } 2 \text { years } \\
\text { investment and } \\
\text { saving }\end{array}$ & & Not worked out & LI & $\operatorname{Yes}^{15 i}$ \\
\hline $\begin{array}{l}\text { ind } 2 \text { years } \\
\text { investment and } \\
\text { saving }\end{array}$ & $\begin{array}{l}\text { Reduced form equation for price } \\
\text { level is of } 3 \text { rd degree after } \\
\text { dropping } 4 \text { money-market } \\
\text { equations (p. 38); not given; } \\
\text { tax functions raise degree to } \\
\text { 6th (p. 40); partly given }\end{array}$ & Not worked out & $\mathrm{Ll}$ & $\operatorname{Yes}^{15 b_{3}}$ \\
\hline $\begin{array}{l}\text { lecade } \\
\text { investment }\end{array}$ & $\begin{array}{l}\text { Reduced form equation for } \\
\text { GNP is of } 9 \text { th degree (p. } 215 \text { ) } \\
\text { not given }\end{array}$ & Not worked out & $\begin{array}{l}\text { LS } \\
\text { LI }\end{array}$ & Yes \\
\hline
\end{tabular}

\section{NOTES TO TABLE I}

(The number before each letter indicates the column concerned)

1a Beginning with 1921 instead of 1922 in a few equations.

All are linear in unknown parameters.

Linear except for the use of absolute magnitudes. Even equations of the form $P Q=V$ are linearized).

6a Tinbergen's consumption equation is in money terms.

ab Also gives a consumption function depending on labour income and nonlabour income.

7a The letter ' $N$ ' or ' $G$ ' indicates whether the investment function is net or gross of depreciation.

In every case except Tinergen's, goverument expenditure and net exports (or total exports if there is an import equation) are essentially a single variable; hence exports are not mentioned in the list except for Tinbergen's model.

${ }^{\circ b}$ Consisting of the gold stock, the Federal Reserve's holdings of securities, Federal Reserve credit to banks, individuals' holdings of bonds and of shares, and the amounts issued of private bonds, government bonds, and shorterm

government debt.

dhe model is entirely in terms of deflated values.

There are 3 and 5 year lags in one interest-rate equation which for some purposes is not essential. , These simplifications involve mainly the linearizing of the model by neglecting the absolute-value character of certain otherwise linear variables.

14: LS means least squares method.

LI means limited information method.

FID means full information method, assuming that the matrix of covariances of disturbances is diagonal, i.e. that the disturbances in each equa-tion are uncorrelated with those in other equa

$\mathrm{R}$ means recursive form method.

15a Ex-post forecasts for 1951-52 are given, together with actual values of the variables, but errors are not calculated and tests are not made. Forecasts for 1953 are also given, based on information available in February 1953, but the actual values for 1953 are not given and no tests are made with p.

15b Forecasts for 1954 are given, prepared in December 1953, but the actual values for 1954 are not given and no tests are made with them. Preliminary figures for the change from 1953 to 1954 are given for a number of variables on $\mathrm{p}$. ix. 
character of all the models is due to the presence of lags and cumulants. In the nonlinear models the reduced forms and final equations are nonlinear too, and though their general character is sometimes indicated they are not spelled out. ${ }^{x}$

The least squares and limited information estimation methods were both used in most of the recent models. It is interesting to compare estimates made by the two methods, for while the superiority of limited information estimates to least squares estimates has been proved (under certain assumptions) ${ }^{2}$ for sample sizes approaching infinity, ${ }^{3}$ not very much is known about their relative biases for small sample sizes ${ }^{4}$. It is regrettable that Klein and Goldberger do not give least squares estimates of their equations so that they may be compared with the limited information estimates. ${ }^{5}$

We are now ready to look at Table II, which summarizes the results of extrapolating the following four models to one or two periods of post-sample data:

\section{Klein (1950), Model III \\ Christ (1951) \\ Klein and Goldberger (1955), Model I \\ Valavanis-Vail (1955)}

The measures of extrapolation error there recorded are of two kinds, corresponding to the two types of questions mentioned at the end of Section IV above. The one labelled ' $\%$ error' is the ratio of the extrapolation error to the actual value, and indicates something about the general level of accuracy attained by the model in question. A low '\% error' is clearly to be desired. The one labelled 'error/S' (or 'error/M') is the ratio of the extrapolation error to the root mean square (or median) error made

\footnotetext{
${ }^{1}$ See note 4 on p. 10 .

${ }^{2}$ Principally, that the model as specified is correct, that its random disturbances are statistically independent of the variables classed as exogenous, and (if it contains lags) that its disturbances are serially uncorrelated. (See Koopmans and Hood (1953), pp. 117-22.

${ }^{3}$ For a good summary see Koopmans and Hood (1953), pp. 132-33, 146-47.

4 Wagner (1954) reports an interesting experiment on this point. He set up an income-investment model with known parameters, then generated 100 samples of size 20 with it, and then estimated the marginal propensity to consume from each sample by least squares and by limited information. The root mean square error of the 100 least squares estimates is slightly smaller than that of the 100 limited information estimates, but the difference appears only in the third or fourth significant figure and is too small to mean anything.

${ }^{5}$ Fox (1956), in reviewing Klein and Goldberger, gives his own calculations of least squares estimates of their equations; they differ little from their limited information estimates.
} 
during the sample, and indicates something about whether the model describes the post-sample data as well as the sample data. A low 'error/s' (or 'error/M') is clearly desirable; when the value is below 1 or not many times greater than 1, the hypothesis that the equation in question describes the post-sample data as well as the sample data cannot be rejected. ${ }^{1}$

The first three models in Table II are extrapolated by means of structural equations, so their errors refer to the performance of individual structural equations. ${ }^{2}$ The Klein-Goldberger Model I is extrapolated by means of reduced form equations, so its errors refer to the forecasts that would have been made if the predetermined variables had been correctly known. It would have been helpful if the authors of all the models had presented errors of both the structural and the reduced form equations.

In comparing the four models it should be remembered that the Klein Model III was extrapolated to 1946 and 1947, five and six years - and very eventful years too - beyond the close of its sample period, while the others were extrapolated into less eventful times. Further, the Christ model and the KleinGoldberger Model I were extrapolated only one and two years beyond their sample periods, respectively. This means that Table II as it stands is somewhat biased against the Klein Model III and in favour of the three others.

Since depreciation is easy to forecast fairly closely, being a sluggish variable, the absolute errors in extrapolating net and gross investment will usually be nearly the same. And since gross investment is much larger than net, the percentage error for extrapolating gross investment will usually be smaller than for net. The Klein-Goldberger data for gross investment and depreciation in 1951-52 indicates that their Model I's percentage errors in forecasting net investment for those years were about 52 per cent and 9 per cent, in contrast to the errors of 28 percent and 18 per cent as given in Table II for gross investment. ${ }^{3} \mathrm{~A}$ similar comment would apply to Valavanis-Vail's error of

${ }^{1}$ An appropriate significance test would ask whether the extrapolation error was larger or smaller in absolute value than a critical amount $\mathrm{k}$, $\mathrm{k}$ being to the product of a critical value of Student's statistic t times the estimated standard deviation of the extrapolation error; this estimated standard deviation is somewhat greater than S (see, for example, Mood (1950), pp. 297-99) so the critical amount $\mathrm{k}$ is typically about $2 \mathrm{~S}$ or $3 \mathrm{~S}$ or more.

2 See note 1 to Table II.

${ }^{3}$ See Klein and Goldberger (1955), p. 81. The percentage error for net is less than for gross in 1952 because of an offsetting error for depreciation. 
TABLE II

Summary of Extrapolations of Four Models

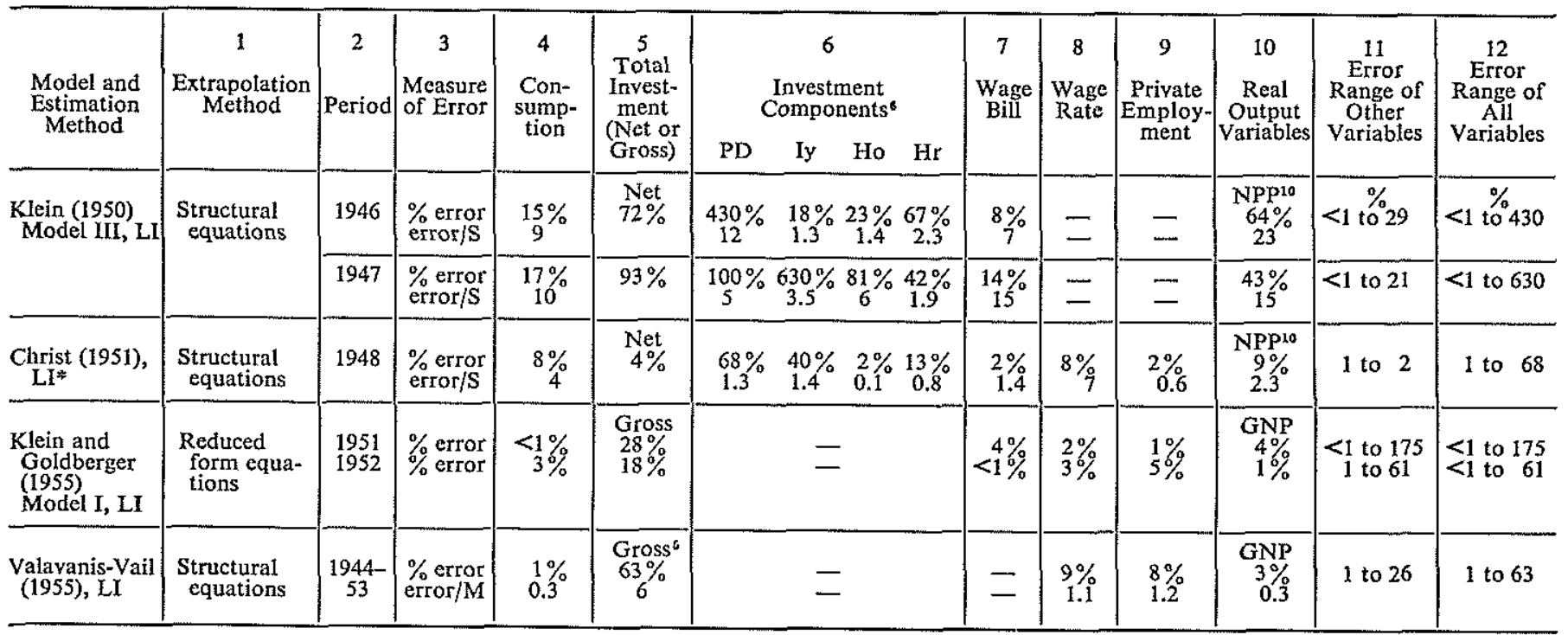

For the number indicates the column concerned)

* For the investment and wage-bill equations in this model the limited information estimates were clearly inferior to the least squares estimates, so the latter were used for 1 Extrapolation of structural tor extrapolations reported here.

case of struation of structural (or reduced form) equations means calculating the error of each structural (or reduced form) equation in the post-sample period. See text. In the under consumption ete. 3 $\%$ error' means the extrapolation error as a per cent of the actual value; 'crror/S' (or 'error/M') means the ratio of the extrapolation error to the root mean square (or median) error during the sample period

5 In this model, the investment variable includes government expenditure.

$6 \mathrm{PD}=$ producers' durable plant and equipment investment. Iy $=$ inventory investment. Ho $=0$ owner-occupied housing investment. Hr $=$ rental housing investment. 
63 per cent for gross investment, were data available. Thus it appears that there has not been very much progress with the investment function since the Klein Model III. ${ }^{1,}{ }^{2}$

The Klein-Goldberger Model I does its job much better than the others do theirs, coming within 5 per cent of the mark in both 1951 and 1952 for the following variables: real; GNP; real national income (not shown separately in Table II), real consumption; employment; the real wage-bill; and the wage rate. It has fairly bad errors for investment and corporate saving, as might be expected. from examining the sampleperiod fits of the corresponding structural equations. ${ }^{3}$

Because the Klein-Goldberger Model $I$ is the most recent of those that have been extrapolated, and in my opinion the best, it may be interesting to record the results of a few simple calculations designed to illuminate further the character of its extrapolation performance. The following table summarizes the cases in which its extrapolations show the right direction of change from the preceding year's situation: ${ }^{4}$

The model's extrapolations may be compared with those

\begin{tabular}{c|c|c|c|c|c|c|c|c|c}
\hline Year & $\begin{array}{c}\text { Real } \\
\text { GNP }\end{array}$ & $\begin{array}{c}\text { Con- } \\
\text { sump- } \\
\text { tion }\end{array}$ & $\begin{array}{c}\text { In- } \\
\text { vest- } \\
\text { ment }\end{array}$ & $\begin{array}{c}\text { Real } \\
\text { wage } \\
\text { bill }\end{array}$ & $\begin{array}{c}\text { Wage } \\
\text { rate }\end{array}$ & $\begin{array}{c}\text { Price } \\
\text { level }\end{array}$ & $\begin{array}{c}\text { Em- } \\
\text { ploy- } \\
\text { ment }\end{array}$ & $\begin{array}{c}\text { Other } \\
\text { variables }\end{array}$ & $\begin{array}{c}\text { All } \\
\text { variables }\end{array}$ \\
\hline 1951. & Yes & - & No & Yes & Yes & Yes & Yes & 4 out of 7 & $\begin{array}{c}9 \frac{1}{2} \text { out of } 14 \\
\text { 1952. }\end{array}$ \\
Yes & Yes & Yes & Yes & Yes & Yes & Yes & 3 out of 7 & 10 out of 14 \\
\hline
\end{tabular}

1 This is borne out by a direct comparison of the residuals of the investment equation in the Klein Model IO (Klein (1950), p. 111, columns headed $\mathrm{u}_{2}^{\prime} \mathrm{ud}_{3}{ }_{3}, \mathrm{ul}^{\prime}{ }_{5}$, and $u_{6}^{\prime}$ ) with the residuals of the investment equations in the Klein-Goldberger models (Klein and Goldberger (1955) pp. 156 and 158, columns 2 and $2^{*}$ ). The latter are, if anything, larger. (The small rise in the price level from 1934, the base of the data in the former, to 1939 , the base of the data in the latter, is not enough to invalidate the broad result of this rough direct comparison.) Both of the KleinGoldberger investment equations miss the drop in investment in 1949 followed by the rise in 1950.

${ }^{2}$ No special merit attaches to the investment equations in my model for their good collective performance in 1948, for they are the same as those in the Klein Model III, refitted to a sample period including the two post-war years of 1946 and 1947. (The latter is also true of my wage-bill equation, but not of the others tabulated.) See also note $\left(^{*}\right)$ to Table II.

${ }^{3}$ Corporate saving is the variable for which the largest errors of 175 per cent and 61 per cent are recorded in Table II. See Klein and Goldberger (1955), pp. 55-6 (graphs of residuals), 156 (tables of residuals), 81 (extrapolations).

4 Figures calculated from Table 11, p. 81. Only fourteen structural equations were used in making extrapolations, the money market equations being dropped, so there are fourteen extrapolations. In each case the correct values of the predetermined variables have been used in extrapolating. No comparison is possible for consumption in 1951 because no change was forecast. 
made by a naive model that simply assumes no change from the previous year. The following table summarizes the cases in which the model's extrapolations are better than those of this naive model: 1

\begin{tabular}{c|c|c|c|c|c|c|c|c|c}
\hline Year & $\begin{array}{c}\text { Real } \\
\text { GNP }\end{array}$ & $\begin{array}{c}\text { Con- } \\
\text { sump- } \\
\text { tion }\end{array}$ & $\begin{array}{c}\text { In- } \\
\text { vest- } \\
\text { ment }\end{array}$ & $\begin{array}{c}\text { Real } \\
\text { wage } \\
\text { bill }\end{array}$ & $\begin{array}{c}\text { Wage } \\
\text { rate }\end{array}$ & $\begin{array}{c}\text { Price } \\
\text { level }\end{array}$ & $\begin{array}{c}\text { Em- } \\
\text { ploy- } \\
\text { ment }\end{array}$ & $\begin{array}{c}\text { Other } \\
\text { variables }\end{array}$ & $\begin{array}{c}\text { All } \\
\text { variables }\end{array}$ \\
\hline 1951. & Yes & Tie & No & Yes & Yes & Yes & Yes & 3 out of 7 & $8 \frac{1}{2}$ out of 14 \\
1952. & Yes & No & No & Yes & Yes & No & No & 1 out of 7 & 4 out of 14 \\
\hline
\end{tabular}

The forecasting procedure advocated by Klein and Goldberger $^{2}$ is to solve the estimated structural equations for the endogenous variables (using given values of the predetermined variables), after either making or not making a change in the estimated constant term of each structural equation according to the following rule: $(a)$ if the structural equation's errors in the preceding few years ${ }^{3}$ are all in the same direction and if there is independent information leading them to expect errors in that direction to continue, then they add to the constant term of that structural equation the error made by that equation in the preceding year; $(b)$ if the structural equation's errors in the preceding few years are not all in the same direction, or if the errors are in the same direction but there is no independent information leading them to expect errors in that direction to continue, then they do not alter the constant term of that structural equation. Unfortunately they do not give the extrapolated values of the endogenous variables for 1951 and 1952 that would be obtained if their procedure were used, and it is impossible for the reader to calculate them because he does not know what Klein and Goldberger would have been led to believe by independent information. However, it would be possible to calculate a set of extrapolations as good as or better than their procedure would yield, by giving them the benefit of doubt as follows: whenever an equation has had errors in the same direction in the preceding three years ${ }^{4}$ so that the question

I See the preceding footnote.

2 Pp. $77-78$.

${ }^{3}$ They say 'four or five years' on p. 77, but require only three years in their forecasts described on pp. 86-87.

I.e. 1948-49-50 in the case of extrapolations for 1951, and 1949-50-51 in the case of extrapolations for 1952. The structural equations that meet this condition are those for corporate profits (1951 and 1952), depreciation (1951 and 1952), and farm income (1952). See p. 86. 
arises whether to adjust the constant term or not, assume that Klein and Goldberger would have adjusted it in all cases where this would have improved the extrapolations expost, and assume that they would not have adjusted it when the adjustment would not have improved the extrapolations ex post. Such a set of extrapolations could then be compared with those of the naive model used above, with the proviso that the comparison would be somewhat biased in favour of the Klein-Goldberger procedure. The computations would be quite laborious, however, for they involve solving the nonlinear structural equations twice, once for 1951 and once for $1952 .^{1}$

Instead of thus testing the Klein-Goldberger forecasting procedure itself, I shall test, in the same way, a linear approximation to it which they present. ${ }^{2}$ This approximation consists essentially in applying their adjustment procedure to the reduced form equations instead of to the structural equations, and its forecasts can be very quickly computed as follows: the error made by the reduced form in calculating the value of an endogenous variable $\mathrm{x}$ in year $\mathrm{t}-1$ is added to the reduced form's extrapolated value of $x$ for year $t$, if both the following requirements are met: (1) the corresponding errors in periods $t-3$, $t-2$, and $t-1$ are all in the same direction; and (2) the extrapolation would be improved by so doing; no such adjustment is made otherwise. The following table shows where this approximation to the Klein-Goldberger forecasting procedure, with the benefit of doubt given to $\mathrm{it}^{3}$ and with the correct values of

1 This would be less laborious for Klein and Goldberger than for others, for they have solved these systems several times already and presumably have specialized capital available in the form of already-set-up machine computation programmes which would make the cost to them less than to others.

2 pp. $79-81$.

3 In deciding whether to add the previous year's reduced form error or not, one presumably should look at the signs of the reduced form errors of the three preceding years. These are not presented by Klein and Goldberger, but can be calculated easily for 1950-51-52 from figures given on p. 81, and in every case except one (corporate saving in 1950) the sign of each structural equation's error in each of these years is the same as that of the same year's error in the reduced form equation containing the variable 'explained' by the structural equation (e.g. consumption for the consumption equation, etc.); compare pp. 81 and 86 . Hence I have used the signs of the corresponding structural equations' errors for 1948 and 1949 to determine whether there was a run of three errors of the same sign or not.

In the case of four of the variables (non-labour non-farm income, employment, national income, and the price level) there is no corresponding structural equation 'explaining' them; this is because among the fourteen structural equations used in extrapolation, four are identities. In the case of each of these four variables, I again gave the benefit of doubt by choosing the better of the two reduced-form extra-polations (adjusted and unadjusted). 
the predetermined variables used, extrapolates better than the naive model used above: ${ }^{1}$

\begin{tabular}{c|c|c|c|c|c|c|c|c|c}
\hline Year & $\begin{array}{c}\text { Real } \\
\text { GNP }\end{array}$ & $\begin{array}{c}\text { Con- } \\
\text { sump- } \\
\text { tion }\end{array}$ & $\begin{array}{c}\text { In- } \\
\text { vest- } \\
\text { ment }\end{array}$ & $\begin{array}{r}\text { Real } \\
\text { wage } \\
\text { bill }\end{array}$ & $\begin{array}{c}\text { Wage } \\
\text { rate }\end{array}$ & $\begin{array}{c}\text { Price } \\
\text { level }\end{array}$ & $\begin{array}{c}\text { Em- } \\
\text { ploy- } \\
\text { ment }\end{array}$ & $\begin{array}{c}\text { Other } \\
\text { variables }\end{array}$ & $\begin{array}{c}\text { All } \\
\text { variables }\end{array}$ \\
\hline 1951. & Yes & Tie & No & Yes & Yes & Yes & Yes & 5 out of 7 & $10 \frac{1}{2}$ out of 14 \\
1952. & Yes & No & No & Yes & Yes & No & No & 2 out of 7 & 5 out of 14 \\
\hline
\end{tabular}

In summary, it may be noted that there are just three variables whose forecasts for both 1951 and 1952 by the Klein-Goldberger Model 1 meet all the requirements discussed above, namely: (1) that the forecasts be in error by less than 5 per cent; (2) that they show the right direction of change from the preceding year; and (3) that they be better than the no-change naive model forecasts. These three variables are real GNP, the real wage bill, and the wage rate. ${ }^{2}$ In either 1951 or 1952 or both, every other variable's forecasts fail to meet one or more of the requirements. Against the Klein-Goldberger Model 1, and hence against each of the others reviewed here, one may say that so far it does well for only a very small proportion of the variables it deals with. For the Klein-Goldberger Model 1, one may say that so far it does well for one of the most important single variables, namely real GNP. The reader may make his own appraisal.

\section{LIST OF REFERENCES}

Barger, Harold, and Lawrence R. Klein (1954), 'A Quarterly Model for the U.S. Economy', Journal of the American Statistical Association 49 (September 1954), pp. 413-37.

Baumol, William J. (1951), Economic Dynamics, New York. Macmillan, 1951.

Christ, Carl F. (1951), 'An Econometric Model for the United States, 1921-1947', in Conference on Research in Business Cycles, New York, National Bureau of Economic Research, 1951, pp. 35-107 (comments, pp. 107-29).

1 The three cases of improvement over the preceding table (showing the performance of the model's unadjusted extrapolations) are non-labour non-farm income and corporate saving in 1951, and depreciation in 1952.

2 It happens that my calculations above, giving the benefit of doubt to the Klein-Groldberger preferred procedure, do not affect this result, for the same three variables meet the requirements whether or not the benefit of doubt is given. 
Clark, Colin (1949), 'A System of Equations Explaining the United States Trade Cycle, 1921 to 1941 ', Econometrica 17 (April 1949), pp. 93-124.

Conference on Research in Income and Wealth (1955), Input-Output Analysis; An Appraisal, Studies in Income and Wealth, Vol. 18, Princeton, Princeton University Press (for the National Bureau of Economic Research), 1955.

Evans, W. Duane and Marvin Hoffenberg (1952), 'The Interindustry Relations Study for 1947', Review of Economics and Statistics V. XXXIV (May 1952), pp. 97-142.

Fox, Karl A. (1956), 'Econometric Models of the United States', Journal of Political Economy LXIV (No.2,April 1956), pp. 128-142.

Hicks, J. R. (1950), A Contribution to the Theory of the Trade Cycle, Oxford Clarendon Press, 1951.

Ichimura, Shinichi (1954), 'Towards a General Nonlinear Macrodynamic Theory of Economic Fluctuations', pp. 192-226 in Kurihara, Post Keynesian Economics, Rutgers, New Jersey, Rutgers Univ. Press, 1954.

Klein, Lawrence R. (1950), Economic Fluctuations in the United States, 1921-1941, New York, Wiley, 1950.

Klein, Lawrence R. and A. S. Goldberger (1955), An Econometric Model of the United States, 1929-1952, Amsterdam, NorthHolland Publishing Co., 1955.

Koopmans, Tjalling C. (1949), 'Identification Problems in Economic Model Construction', Econometrica 17 (April 1949), pp. 125-44. Also reprinted in Hood and Koopmans, Studies in Econometric Method, New York, Wiley, 1953.

Koopmans, Tjalling C. and William C. Hood (1953), 'The Estimation of Simultaneous Linear Relationships', Chapter VI in Hood and Koopmans, Studies in Econometric Method, New York, Wiley, 1953.

Leontief, Wassily W. (1951), The Structure of American Economy, (Second Edition), New York, Oxford, 1951.

Leontief, Wassily, et al. (1953), Studies in the Structure of the American Economy, New York, Oxford, 1953.

Marshak, Jacob (1953), 'Economic Measurements for Policy and Prediction', Chapter I in Hood and Koopmans, Studies in Econometric Method, New York, Wiley, 1953.

Matthews, R. C. O. (1954), 'Capital Stock Adjustment Theories of the Trade Cycle and the Problem of Policy', pp. 170-90 in Kurihara, Post Keynesian Economics, Rutgers, New Jersey, Rutgers University Press, 1954.

Mood, Alexander McFarlane (1950), Introduction to the Theory of Statistics, New York, McGraw Hill, 1950. 
Netherlands Economic Institute (1953), Input-Output Relations, Leiden, Stenfert Kroese N.V. 1953.

Samuelson, Paul A. (1939), 'Interaction between the Multiplier Analysis and the Principle of Acceleration', Review of Economic Statistics 1939, pp. 75-78.

Samuelson, Paul A. (1947), Foundations of Economic Analysis, Cambridge, Mass. Harvard University Press, 1947.

Stone, J. R. N. (1955), Conceptual Problems in Input-Output Work, Paris, O.E.E.C., 1955 (mimeographed).

Stone, J. R. N. and S. J. Prais (1952), 'Systems of Aggregative Index Numbers and their Compatibility', Economic Journal LXII (September 1952), pp. 565-83.

Tinbergen, J. (1939), Business Cycles in the United States of America, 1919-1932, Geneva, L. of N. Economic Intelligence Service, 1939.

U.S. Department of Commerce (1951), National Income, 1951 Edition (Supplement to the Survey of Current Business), Washington, U.S. Government Printing Office, 1951.

U.S. Department of Commerce (1954), National Income, 1954 Edition (supplement to the Survey of Current Business), Washington, U.S. Government Printing Office, 1954.

Valavanis-Vail, Stefan (1955), 'An Econometric Model of Growth', U.S.A., 1869-1953, American Economic Review XLV (May 1955), pp. 208-21.

Wagner, Harvey M. (1954), A Monte Carlo Study of Estimates of Simultaneous Linear Structual Equations, Stanford University Economics Dept., 1954. 